\title{
The art and science of clinical pediatric education
}

\author{
Paul L.P. Brand ${ }^{1,2} \cdot$ Piet L. Leroy ${ }^{3} \cdot$ J. Peter de Winter ${ }^{4,5}$ \\ Published online: 27 February 2021 \\ (C) The Author(s), under exclusive licence to Springer-Verlag GmbH, DE part of Springer Nature 2021
}

Pediatricians educate people every day: their patients and their caregivers, medical students, residents, nurses, allied health professionals [1]. The word "doctor" is derived from the Latin verb docere, to teach. Teaching is a key daily activity of pediatricians throughout Europe and the rest of the world. Despite this importance of teaching, both in consultations with patients and parents and in training future doctors and pediatricians, most pediatricians have not received any formal training in key educational principles, knowledge, and skills. Most doctors who teach patients or future doctors are autodidacts: they teach because they believe they should, or want to teach, and they give it their best effort. Teaching in the clinical workplace is commonly based on personal experience (both as a doctor and as a learner earlier in the career), common sense, and the conviction that transferring knowledge is the key to learning [2].

Medical education science is a relatively new field of research and scholarship, but a highly engaging and productive one. Over the past decades, major advances have been made in understanding how adults learn, how they acquire new knowledge, master new skills, and develop the professional identity of a physician $[3,4]$. In addition, medical education research helps us in understanding how we, as clinician-educators, can promote effective learning

Paul L.P. Brand

p.l.p.brand@isala.nl

1 Isala Academy, Department of Medical Education and Faculty Development, Isala Hospital, Zwolle, The Netherlands

2 Lifelong Learning Education and Assessment Research Network (LEARN), University of Groningen and University Medical Centre, Groningen, The Netherlands

3 Department of Pediatrics, Maastricht University Medical Centre, Maastricht, the Netherlands

4 Department of Pediatrics, Spaarne Gasthuis, Hoofddorp/ Haarlem, The Netherlands

5 Department of Development and Regeneration, KU Leuven, Leuven, Belgium in our students and residents, our future colleagues. For example, this has led to the understanding that in order to use new knowledge in clinical practice, medical learners need to be encouraged and supported to process the knowledge, rather than listen to it being delivered by a more experienced physician [5]. In addition, it has been shown that pediatric and other residents flourish in a supportive learning environment, rather than work hard, see lots of patients, and learn on the fly $[6,7]$. Such insights from educational science may have a considerable impact on our daily educational practice in the workplace.

In the past decade, major changes have taken place in the education of future pediatricians. Most European countries have shifted from time-based postgraduate pediatric education curricula to competency-based pediatric education $[8,9]$. European work hours regulations have reduced residents' working hours and hence their exposure to pediatric cases $[10,11]$. Increasingly, junior doctors wish to balance their work with room for family, hobbies, and personal development $[12,13]$. Pediatrics is increasingly viewed as a profession, and no longer as a calling.

Thus, there are many reasons to provide European pediatricians with an up-to-date overview of the art and science of clinical pediatric education. This is the reason why the Editorial Board of the European Journal of Pediatrics has decided to launch a series of papers outlining principles and practice of pediatric teaching. This series will cover topics ranging from the physiology of learning, providing feedback and coaching, teaching procedural skills, and the importance of trust in pediatric education and practice, to the use of digital teaching and blended learning.

Each paper in this series begins with a clinical teaching scenario. Evidence from educational research is presented in an accessible, hands-on format with practical tips and tricks to support busy clinicians who wish to hone their clinical teaching skills. The papers are written by teams of pediatrician-educators and medical education scholars, to integrate medical education science and pediatric teaching practice. We trust this new series will inspire and support 
you to become an even better version of the clinical teacher that resides in all of us.

Authors' contributions The three authors developed the concept and content of the Series on the Art and Science of Clinical Pedriatic Education in mutual discussions. PB wrote the draft version of this opening editorial, PL and PdW provided feedback and suggestions. All authors agree on the published version.

\section{References}

1. Brand PL, Stiggelbout AM (2013) Effective follow-up consultations: the importance of patient-centered communication and shared decision making. Paediatr Respir Rev 14:224-228. https:// doi.org/10.1016/j.prrv.2013.01.002

2. Reilly BM (2007) Inconvenient truths about effective clinical teaching. Lancet 370:705-711. https://doi.org/10.1016/S0140-6736(07) 61347-6

3. Davis DA, McMahon GT (2018) Translating evidence into practice: lessons for CPD. Med Teach 40:892-895. https://doi.org/10. 1080/0142159X.2018.1481285

4. Taylor DC, Hamdy H (2013) Adult learning theories: implications for learning and teaching in medical education: AMEE guide no. 83. Med Teach 35:e1561-e1e72. https://doi.org/10.3109/ 0142159X.2013.828153

5. van der Vleuten CP, Driessen EW (2014) What would happen to education if we take education evidence seriously? Perspect Med Educ 3:222-232. https://doi.org/10.1007/s40037-014-0129-9

6. Blair M, Wortley E, McGuff K (2020) Placing education at the Centre of the outpatient clinic improves learning and experiences for everyone using the multilevel attainment of learning, teaching and support (MALTS) approach. Arch Dis Child Educ Pract Ed 105:2-6. https://doi.org/10.1136/archdischild-2019-317544

7. Nordquist J, Hall J, Caverzagie K, Snell L, Chan MK, Thoma B, Razack S, Philibert I (2019) The clinical learning environment. Med Teach 41:366-372. https://doi.org/10.1080/0142159X.2019. 1566601

8. Scheele F, Teunissen P, Luijk SV, Heineman E, Fluit L, Mulder H, Meininger A, Wijnen-Meijer M, Glas G, Sluiter H, Hummel T (2008) Introducing competency-based postgraduate medical education in the Netherlands. MedTeach 30:248-253. https://doi.org/10. $1080 / 01421590801993022$

9. van der Vleuten CP (2015) Competency-based education is beneficial for professional development. Perspect Med Educ 4:323-325. https://doi.org/10.1007/s40037-015-0232-6

10. Moonesinghe SR, Lowery J, Shahi N, Millen A, Beard JD (2011) Impact of reduction in working hours for doctors in training on postgraduate medical education and patients' outcomes: systematic review. BMJ 342:d1580. https://doi.org/10.1136/bmj.d1580

11. Taylor TS, Teunissen PW, Dornan T, Lingard L (2017) Fatigue in residency education: understanding the influence of work hours regulations in Europe. Acad Med 92:1733-1739. https://doi.org/ 10.1097/ACM.0000000000001831

12. Blayney S, Crowe A, Bray D (2014) Survival as medical registrar on call: remember the doughnut. Clin Med (Lond) 14:506-509. https://doi.org/10.7861/clinmedicine.14-5-506

13. Olmos-Vega FM, Dolmans D, Vargas-Castro N, Stalmeijer RE (2017) Dealing with the tension: how residents seek autonomy and participation in the workplace. Med Educ 51:699-707. https://doi.org/10.1111/medu.13326

Publisher's note Springer Nature remains neutral with regard to jurisdictional claims in published maps and institutional affiliations. 